\title{
基于斑块尺度的云南省景观生态安全时空演变及归因
}

\author{
施馨雨 ${ }^{1}$, 赵篗青 ${ }^{1, *}$, 普军伟 ${ }^{1}$, 冯 严 ${ }^{1}$, 周世杰 ${ }^{1}$, 和春兰 ${ }^{2}$ \\ 1 云南大学地球科学学院,昆明 650500 \\ 2 云南国土资源职业学院,昆明 652501
}

\begin{abstract}
摘要: 随着人类活动的需求增强和范围扩张, 建设开发、农林种植等行为不断侵占和切分原有土地系统, 导致区域景观斑块小型 化和破碎化,产生了诸多生态问题。云南既是我国西南生态安全屏障, 同时也是生态环境比较脆弱敏感的地区, 研究云南省景 观生态安全及其影响因素, 对区域、国家乃至国际生态安全具有重要意义。以云南省为研究对象, 提出基于斑块尺度的景观生 态安全评价方法评估云南省 1990-2018 年近三十年的景观生态安全,采用空间自相关方法分析其时空演变规律,并通过地理 探测器识别影响景观生态安全的主要驱动因子。结果表明: (1) 与传统生态安全评价模型相比, 斑块尺度的景观生态安全模型 对区域内部景观生态安全的变化更敏感,能够反映区域内部多年景观生态安全状况的细微变化。(2) 云南省 1990-2018 年整 体生态安全成本成波动上升趋势,其中“三屏两带” 地区的景观生态安全状况提升明显,而滇中城市群外围以及滇东南喀斯特 地带的部分区域有所下降。云南省景观生态安全的 Global Moran's I 指数平均值为 -0.293 , 区域内部斑块破碎, 空间分布上具有 离散性。(3) 云南省景观生态安全状况目前主要受到人口密度、年平均温度和海拔高度的影响; 从交互驱动方面看, 云南省景 观生态安全空间分布是自然和人文因子共同作用的结果,其中自然因子的交互驱动作用更明显。研究结果可为云南省景观生 态安全格局优化提供理论支撑与科学依据。
\end{abstract}

关键词: 景观生态安全; 斑块尺度;空间自相关; 地理探测器;云南省

\section{Spatio-temporal evolution and attribution of Landscape Ecological Security at patch scale in Yunnan Province}

\author{
SHI Xinyu ${ }^{1}$, ZHAO Xiaoqing ${ }^{1, *}$, PU Junwei ${ }^{1}$, FENG Yan ${ }^{1}$, ZHOU Shijie ${ }^{1}$, HE Chunan ${ }^{2}$ \\ 1 School of Earth Science, Yunnan University, Kunming 650500, China \\ 2 Yunnan Land and Resources Vocational College, Kunming 652501, China
}

\begin{abstract}
With the increasing demand and scope expansion of human activities, construction and development, agriculture and forestry planting and other behaviors continue to encroach on and divide the original land system, resulting in the miniaturization and fragmentation of regional landscape patches, and ecological problems. Yunnan is not only an ecological security barrier in southwestern China but also an area with a fragile ecological environment. Study of landscape ecological security and its influencing factors in Yunnan Province is of great significance to regional, national, and even international ecological security. Taking Yunnan Province as the research object, this paper develops a landscape ecological security evaluation method in patch scale to evaluate the landscape ecological security of Yunnan Province in the past 30 years from 1990 to 2018 and uses the spatial autocorrelation method to analyze its spatio-temporal evolution law. And the main driving factors affecting landscape ecological security are identified by geographic detectors. The results show that: (1) compared with the traditionally ecological security evaluation model, the patch-scale landscape ecological security model is more
\end{abstract}

基金项目: 国家自然科学基金(42061052);云南省科技厅-云南大学联合基金(2018FY001-017);云南省教育厅科学研究基金项目(2020Y0030) 收稿日期: 2020-11-22; 采用日期:2021-08-16

*通讯作者 Corresponding author.E-mail: xqzhao@ynu.edu.cn 
sensitive to the changes of landscape ecological security and can reflect the subtle changes of landscape ecological security in the region for many years. (2) The overall ecological security cost of Yunnan Province fluctuated and increased from 1990 to 2018 , in which the landscape ecological security in the area of "three screens and two belts" improved obviously, while the periphery of the urban agglomeration in central Yunnan and some areas in the karst zone in southeastern Yunnan decreased. The average Global Moran's I index of landscape ecological security in Yunnan Province is -0.293 . The patches in the region are divided and the spatial distribution is discrete. (3) At present, the situation of landscape ecological security in Yunnan Province is mainly affected by population density, annual average temperature, and altitude; from the aspect of the interactive drive, the spatial distribution of landscape ecological security in Yunnan Province is the result of the joint action of natural and human factors, among which the interactive driving effect of natural factors is more obvious. The results can provide theoretical support and a scientific basis for the optimization of landscape ecological security patterns in Yunnan Province.

Key Words : landscape ecological security; patch scale; spatial autocorrelation; geodetector; Yunnan Province

生态安全是整个生态系统健康水平与完整状况的表征 ${ }^{[1]}$ 。随着人类活动对环境的压力不断增大,生态 安全受到严重威胁。我国逐渐认识到资源环境的重要性,倡导遵循尊重自然、顺应自然、保护自然的生态文明 理念 ${ }^{[2]}$ 。云南响应国家战略部署, 确立了争当新时代生态文明建设排头兵的目标 ${ }^{[3-4]}$ 。近年来,云南省生态 安全越来越受到学者们的关注 ${ }^{[5-10]}$, 但对于省域的生态安全评估仍然薄弱, 难以从宏观层面指导生态文明建 设, 亟需开展相应研究。

景观生态评价与景观格局是景观生态学的重要议题, 如 Peng ${ }^{[11]}$ 将生态退化风险与生态安全结合起来构 建生态安全格局识别的量化框架; Francisco Aguilera ${ }^{[12]}$ 引入景观格局指数分析城市扩张的空间特征; Ma 则通 过相关性来确定影响生态安全的主要景观格局指数 ${ }^{[13]}$, 当今国际景观生态研究越来越重视格局与过程的综 合 ${ }^{[14]}$ 、驱动机制 ${ }^{[15-16]}$ 和综合评价 ${ }^{[17]}$ 的研究,但使用景观格局指数研究区域生态安全的文献较少。我国景观 生态研究始于 20 世纪 90 年代, 如俞孔坚等认为景观规划设计在生物多样性保护中起着决定性的作用 ${ }^{[18]}$, 并 采用最小阻力面模型来判别生物多样性的景观生态安全格局 ${ }^{[19]}$; 肖笃宁等则将生态安全定义为人类在生产、 生活与健康等方面不受生态破坏与环境污染等影响的保障程度 ${ }^{[20]}$, 并基于此提出了干旱区生态环境建设研 究的理论与方法以及生态建设的策略 ${ }^{[21]}$; 傅伯杰等提出的“区域生态安全格局” 是对景观安全格局研究的发 展, 适应了生物保护和生态恢复研究的发展需求 ${ }^{[22-23]}$; 陈利顶等提出了 “源汇” 景观概念 ${ }^{[24]}$, 并基于此提出景 观空间负荷对比指数 ${ }^{[25]}$, 来定量评价景观格局对特定过程的影响。景观生态安全的研究方法和理论呈现多 样性特征。但是, 目前学者对于生态安全评价局限于类型尺度和景观尺度, 从斑块尺度对生态安全进行评价 的研究很少; 且传统景观生态安全评价模型大多是对省、市、区的整体评价, 评价结果反映在地图上是一种离 散或分段式的变化, 很难反映生态安全变化的过渡特征。基于此, 本研究从斑块角度对景观生态安全评价模 型进行修正, 其评价结果在数值上连续, 能够更准确地反映景观生态安全的过渡特征, 对区域景观生态安全评 价更具现实意义和指导意义。

云南既是我国西南生态安全屏障, 又是与南亚、东南亚各国人民同为生态命运与生态利益的共同体, 承担 着维护区域、国家乃至国际生态安全的重大职责。同时,云南又是生态环境比较脆弱敏感的地区,保护生态环 境和自然资源的责任重大。因此,科学研究云南省生态安全特征及其驱动因子具有重要现实意义。研究通过 修正类型尺度景观生态安全评价模型, 从斑块尺度评估云南省 1990-2018 年的景观生态安全特征, 分析其时 空演变规律并探讨影响云南省景观生态安全的主要驱动因子, 为生态安全评价及其时空变化特征和驱动力研 究提供了参考。研究结果可为我国西南地区景观生态安全格局优化提供科学依据, 为维护我国西南生态安全 屏障,维护区域、国家乃至国际生态安全提供有益支撑。 


\section{1 数据与方法}

\section{1 研究区概况}

云南省位于中国西南部 $\left(21^{\circ} 8^{\prime}-29^{\circ} 15^{\prime} \mathrm{N}, 97^{\circ} 31^{\prime}-106^{\circ} 11^{\prime} \mathrm{E}\right)$, 总面积 39.41 万 $\mathrm{km}^{2}$; 东邻贵州、广西, 北连 四川、西藏,西与印度、缅甸接壤, 南部和老挝、越南毗邻 (图 1)。云南属山地高原地形, 自西北向东南呈阶梯 状下降,平均海拔为 $2000 \mathrm{~m}$ 。全省气候干湿季分明,年均降水量 $1260 \mathrm{~mm}$, 其中 $85 \%$ 集中在湿季,年温差小, 日 温差大; 土壤类型分布从南向北依次为砖红壤、赤红壤和红壤; 云南省森林覆盖率为 $62.4 \%$,水平地带和垂直 地带分异明显。2019 年全省 GDP 达到 23223.75 亿元, 同比增长 $8.1 \%$,增长速度高于全国 2.0 个百分点; 年末 全省常住人口 4858.3 万人,城镇化率达 $48.91 \%$ 。生态保护红线约占全省总面积的 $30.90 \%$, 主要分布在青藏 高原南缘滇西北高山峡谷生态屏障、哀牢山一无量山山地生态屏障、南部边境热带森林生态屏障等生物多样 性富集及水源涵养重要区域,以及金沙江、澜沧江、红河干热河谷地带和东南部喀斯特地带水土保持重要区 域,构成了云南省生态保护红线“三屏两带”的空间分布格局。

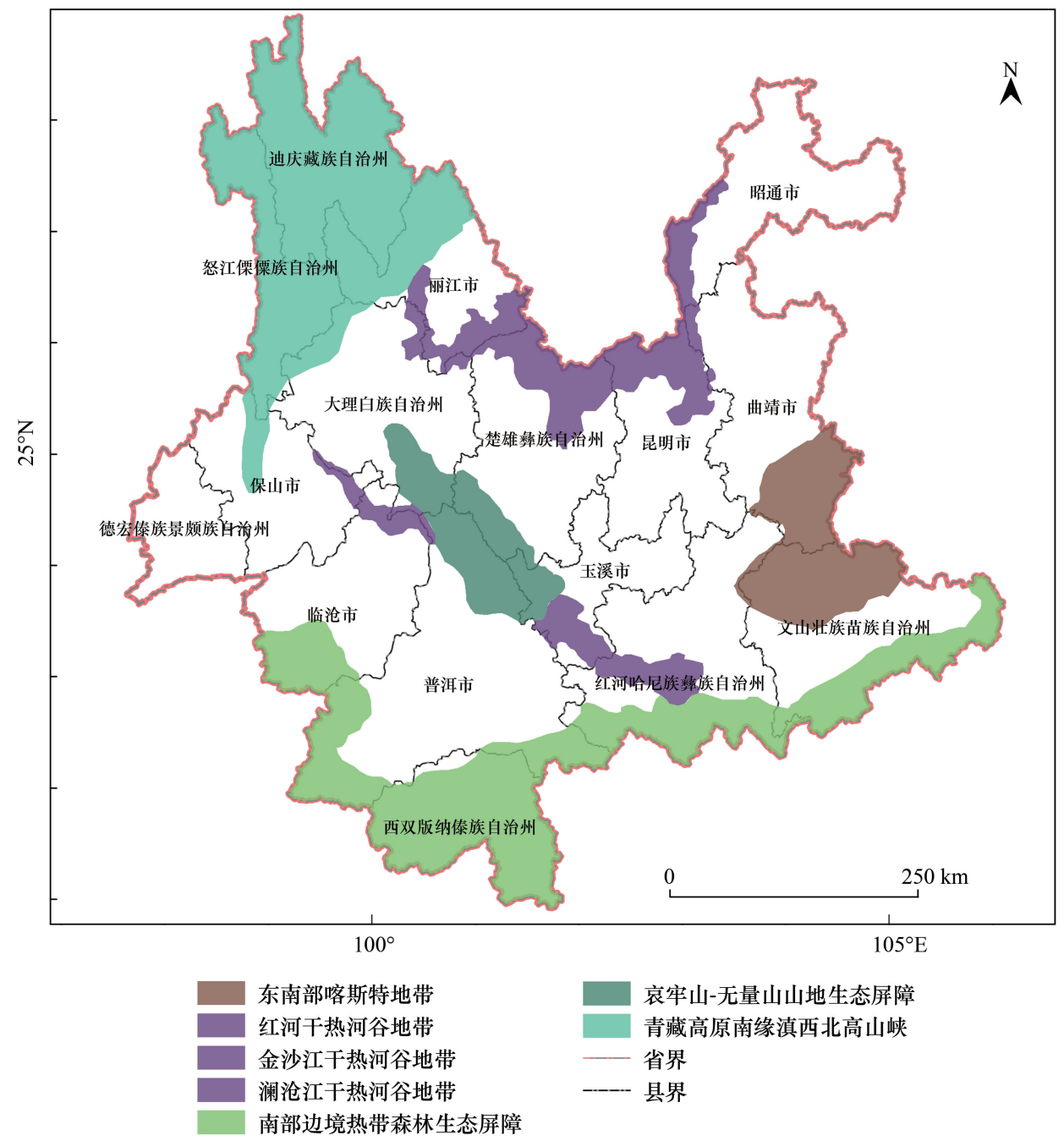

图 1 研究区区位图

Fig.1 Location map of study area

1.2 数据来源与预处理

本研究收集了云南省的土地利用、河流水系、基础设施、数字地形、气象站点、社会经济等数据(表 1 ) 并根 
据云南省土地利用现状特征及研究要求,运用 ArcGIS10.7 软件将土地利用数据重分类为水田、旱地、有林地、 灌木林、疏林地、其他林地、高覆盖度草地、低覆盖度草地、水域、城乡用地、未利用地 11 种景观类型, 并将所有 栅格数据分辨率统一到 $1 \mathrm{~km} \times 1 \mathrm{~km}$ 。

表 1 数据名称及来源

Table 1 Data name and source

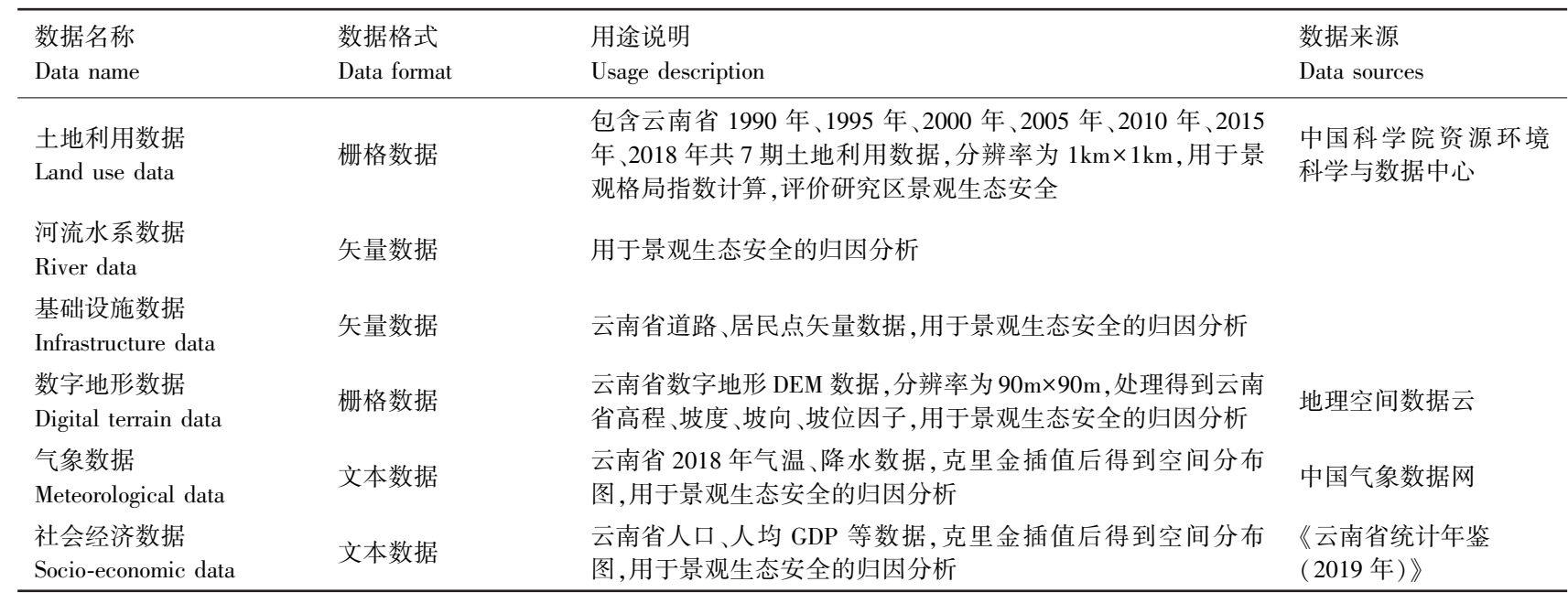

\section{3 研究方法}

1.3.1 斑块尺度下的景观生态安全评价模型构建

本研究选取斑块尺度的景观格局指数对类型尺度景观生态安全模型进行修正,得到斑块尺度景观生态结 构安全度; 以生态系统服务价值作为景观生态功能安全的表达, 构建斑块尺度生态系统功能安全度模型; 最 后, 将结构安全度和功能安全度两者的几何平均值作为评价单元的景观生态安全指数, 得到斑块尺度景观生 态安全评价模型。

(1) 类型尺度景观生态结构安全模型

参照陈鹏 ${ }^{[26]}$ 、裴欢 ${ }^{[27]}$ 等人的研究成果, 构建类型尺度景观生态脆弱度 (Landscape Ecological Frangibility of Class, LEFC) 模型为:

$$
\text { LEFC }=a \times \text { SHAPE_AM }+b \times \text { FRAC_AM }+c \times \text { DIVISION }
$$

式中, LEFC 为类型尺度的景观生态脆弱度; $\mathrm{SHAPE} \_\mathrm{AM}$ 为类型尺度的面积加权平均形状因子; FRAC_AM 为 类型尺度的面积加权分维数; DIVISION 为类型尺度的分离度。根据李晓燕 ${ }^{[28]}$ 、彭文君 ${ }^{[29]}$ 等人的研究结果, 设 置未利用地景观类型的 $a 、 b 、 c$ 值为 $0.2 、 0.3 、 0.5$, 其他景观类型的 $a 、 b 、 c$ 值为 $0.5 、 0.3 、 0.2$ 。

参考前人研究成果, 选择能够表示类型尺度景观结构破碎状况和形状复杂程度的景观格局指数构建类型 尺度景观生态结构安全度 (Landscape Ecological Security of Class, LESC) 模型为:

$$
\mathrm{LESC}=1-(E D+P D) \times \mathrm{LEFC}
$$

式中, LESC 为类型尺度的景观生态结构安全度; $E D$ 为类型尺度的边界破碎度; $P D$ 为类型尺度的景观破碎 度; LEFC 为类型尺度的景观脆弱度。

(2) 斑块尺度景观生态结构安全度模型

本研究通过选取斑块尺度下能够表示斑块的形状、复杂程度和连通性的景观指数, 即斑块面积 (AREA)、 形状指数 (SHAPE)、分维数 (FRAC) 和邻近度 (PROX), 作为修正因子对类型尺度景观生态结构安全度模型 进行修正, 构建斑块尺度景观生态结构安全度 (Landscape Ecological Security of Patch, LESP) 模型:

$$
\mathrm{LESP}=(\alpha \times \mathrm{AREA}+\beta \times \mathrm{SHAPE}+\gamma \times \mathrm{FRAC}+\mu \times \mathrm{PROX}+) \times \mathrm{LESC}
$$

其中:LESP 为斑块尺度景观生态结构安全度;LESC 为类型尺度景观生态结构安全度; $\alpha 、 \beta 、 \gamma \mu$ 分别为斑 
块面积、形状指数、分维数、邻近度的权重。

采用熵权法确定各斑块修正因子的权重 (表 2)。为了简便计算,将信息熵较小 (不足 0.01 ) 的形状指数 和分维数修正因子剔除。最终构建的斑块尺度景观生态结构安全模型为:

$$
\text { LESP }=(\alpha \times \text { AREA }+\mu \times \text { PROX }) \times \text { LESC }
$$

表 2 斑块修正因子权重

Table 2 The weight of patch modification factor

\begin{tabular}{ccccc}
\hline 年份 Year & AREA & SHAPE & FRAC & PROX \\
1990 & 0.423893 & 0.000111 & 0.000700 & 0.003452 \\
1995 & 0.456330 & 0.000404 & 0.002304 & 0.539814 \\
2000 & 0.421243 & 0.000251 & 0.003391 & 0.576202 \\
2005 & 0.455060 & 0.000341 & 0.002310 & 0.541208 \\
2010 & 0.416218 & 0.000249 & 0.003783 & 0.54322 \\
2015 & 0.452417 & 0.000407 & 0.002418 \\
2018 & 0.459309 & 0.000308 & 0.537964 \\
\hline
\end{tabular}

表格中所有修正因子均为斑块尺度下的景观格局指数,其中 AREA 代表面积( area),SHAPE 代表形状指数 ( shape index),FRAC 代表分维数 ( fractal dimension), PROX 代表邻近度 ( proximity)

(3) 斑块尺度景观生态功能安全度模型

生态系统服务是指生态系统与生态过程所形成及维持的人类赖以生存的自然环境条件与效用 ${ }^{[30]}$ 。将每 一个景观斑块的类型看作一种生态系统, 将生态系统服务价值与景观生态功能结合起来, 即可以用生态系统 服务价值对景观生态功能安全进行定量化表达。参考赵䈶青等人 ${ }^{[31]}$ 的研究成果, 用生态服务价值当量值作 为各景观类型的功能表征。参考前人的研究成果 ${ }^{[32-36]}$,结合研究区的实际情况,构建云南省各景观斑块类型 的景观生态功能安全度 (表 3 )。

表 3 云南省各景观斑块类型的景观生态功能安全度

Table 3 Landscape Ecological Function Safety Index of Different Landscape Patch Classes in Yunnan Province

\begin{tabular}{|c|c|c|c|c|c|c|c|c|c|c|c|}
\hline $\begin{array}{c}\text { 斑块类型 } \\
\text { Patch } \\
\text { type }\end{array}$ & $\begin{array}{c}\text { 水田 } \\
\text { Paddy } \\
\text { field }\end{array}$ & $\begin{array}{c}\text { 旱地 } \\
\text { Dryland }\end{array}$ & $\begin{array}{c}\text { 有林地 } \\
\text { Forested } \\
\text { land }\end{array}$ & $\begin{array}{c}\text { 灌木林 } \\
\text { Shrubbery }\end{array}$ & $\begin{array}{l}\text { 疏林地 } \\
\text { Opening }\end{array}$ & $\begin{array}{c}\text { 其他林地 } \\
\text { Other } \\
\text { forest } \\
\text { land }\end{array}$ & $\begin{array}{c}\text { 高覆盖 } \\
\text { 度草地 } \\
\text { High } \\
\text { coverage } \\
\text { grassland }\end{array}$ & $\begin{array}{c}\text { 低覆盖 } \\
\text { 度草地 } \\
\text { Low } \\
\text { coverage } \\
\text { grassland }\end{array}$ & $\begin{array}{l}\text { 水域 } \\
\text { Waters }\end{array}$ & $\begin{array}{l}\text { 城乡用地 } \\
\text { Urban and } \\
\text { rural land }\end{array}$ & $\begin{array}{c}\text { 未利用地 } \\
\text { Unutilized } \\
\text { land }\end{array}$ \\
\hline ESV & 6.74 & 5.45 & 17.24 & 15.39 & 5.17 & 13.47 & 5.72 & 2.00 & 36.29 & 0.40 & 0.10 \\
\hline
\end{tabular}

ESV (Ecosystem Service Value) 指生态系统服务当量因子,即生态系统所产生的生态服务价值的相对大小,在本研究中用于表征各景观类型的景观生态功能安 全度

（4）斑块尺度景观生态安全模型

景观结构是景观功能发挥的基础, 景观功能也体现了景观要素的结构 ${ }^{[37]}$ 。将斑块尺度的景观生态结构 安全度和景观生态功能安全度的几何平均值作为斑块尺度景观生态安全指数值, 构建斑块尺度景观生态安全 评价模型 (Landscape Ecological Security Index,LESI) :

$$
\mathrm{LESI}=\sqrt{\mathrm{LESP} \times \mathrm{ESV}}
$$

式中, LESI 为斑块尺度景观生态安全指数;LESP 为斑块尺度景观生态结构安全度; ESV 为斑块尺度景观生态 功能安全度。

\subsection{2 景观生态安全空间数据探索}

采用空间自相关方法来分析景观生态安全的空间分布特征及异质性。Global Moran's I 能够反映空间分 布是否具有聚散特征, 其值范围为 $[-1,1]$ 。若值大于零, 说明景观生态安全空间分布为正相关关系, 小于零 则为负相关关系; 绝对值越接近 1 表明空间相关性越强, 等于 0 表示景观生态安全在空间上呈随机分布。 
使用 Local Moran's I 指数研究斑块尺度景观生态安全的关联性,探究云南省斑块尺度景观生态安全的空 间异质性。“高-高”集聚和“低-低”集聚表示局部空间的景观生态安全分布呈正相关，“高-低”集聚和“低高”集聚则表示为空间负相关，“不显著”则表明斑块景观生态安全没有空间聚散特征。

\subsection{3 景观生态安全归因分析方法}

云南省地形地貌复杂、气候条件多变、生态环境脆弱、生态系统种类丰富, 导致区域内景观生态安全变化 的原因复杂。参考国内外相关研究成果,结合云南省的地域特征,选取海拔高度 $\left(X_{1}\right)$ 、坡向 $\left(X_{2}\right)$ 、坡位 $\left(X_{3}\right)$ 、 年平均温度 $\left(X_{4}\right)$ 、年平均降水 $\left(X_{5}\right)$ 、人口密度 $\left(X_{6}\right)$ 、人均生产总值 $\left(X_{7}\right)$ 、距水系距离 $\left(X_{8}\right)$ 和距道路距离 $\left(X_{9}\right)$ 共 9 个因子与 2018 年云南省景观生态安全评价结果进行分析。

根据景观格局指数的粒度效应 ${ }^{[38-41]}$, 对比 $1 \mathrm{~km} \times 1 \mathrm{~km} 、 2 \mathrm{~km} \times 2 \mathrm{~km} 、 5 \mathrm{~km} \times 5 \mathrm{~km} 、 10 \mathrm{~km} \times 10 \mathrm{~km}$ 格网下的景观格 局指数值的变化趋势。结果 $10 \mathrm{~km} \times 10 \mathrm{~km}$ 格网下景观格局指数值变化平稳, 因此作为最佳的分析尺度。格网 内各指标的值计算方法如下:

$$
\begin{aligned}
& \operatorname{LESI}_{i}=\frac{\sum_{j}^{n} \operatorname{LESI}_{i j} \times A_{i j}}{A} \\
& X_{i k}=\frac{\sum_{\mathrm{j}}^{n} X_{i j k} \times A_{i j}}{A}
\end{aligned}
$$

式中, LESI 为第 $i$ 个格网的景观生态安全指数, $n$ 为第 $i$ 个格网内的斑块总数, $\operatorname{LESI}_{\mathrm{ij}}$ 为第 $i$ 个格网内的第 $j$ 个 斑块的景观生态安全指数, $A_{i j}$ 为第 $i$ 个格网内的第 $j$ 个斑块的面积, $A$ 为格网面积; $X_{i k}$ 为第 $i$ 个格网的第 $k$ 个驱 动因子的值, $X_{i j k}$ 为第 $i$ 个格网内第 $j$ 个玟块的第 $k$ 个驱动因子的值。

地理探测器是探测空间分异性以及揭示其背后驱动力的一组统计学方法 ${ }^{[42]}$ 。计算方式如下:

$$
q=1-\frac{\sum_{h=1}^{L} N_{h} \times \sigma_{h}^{2}}{N \times \sigma^{2}}=1-\frac{\mathrm{SSW}}{\mathrm{SST}}
$$

式中, $q$ 的值域为 $[0,1]$, 值越大说明自变量 $X$ 对属性 $Y$ 的解释力越强, 反之越弱; $h=1, \cdots, L$ 为变量 $Y$ 或因子 $X$ 的分类; $N_{h}$ 和 $N$ 分别为类 $h$ 和全区的单元数; $\sigma_{h}^{2}$ 和 $\sigma^{2}$ 分别是类 $h$ 和全区的 $Y$ 值的方差; SSW 和 SST 分别为 层内方差之和和全区总方差。

\section{2 结果与分析}

2.1 1990-2018 年云南省景观生态安全时空变化特征

\subsection{1 景观生态安全时间变化特征}

云南省基于类型尺度景观生态结构安全度 ( LESC) 的变化趋势平稳, 最大值从 0.998 增长到 1.00 , 最小值 从 0.460 减少到 0.399 ,数据变化幅度较小, 难以反映云 南省景观生态安全的具体变化特征;而修正后的景观生 态安全指数 (LESI) 呈上升趋势, 最大值从 2.604 增长到 2.999 (图 2), 且年际间差异明显。表明修正后的景观 生态安全评价模型对景观生态安全的变化更加敏感。 由于云南省破碎斑块较多, 斑块面积很小, 导致其 LESI 最小值接近于 0 且变化不大。

云南省景观生态安全各分区面积占比变化为: 极危 险区减少 $1.39 \%$ 、危险区减少 $3.58 \%$ 、较危险区增加

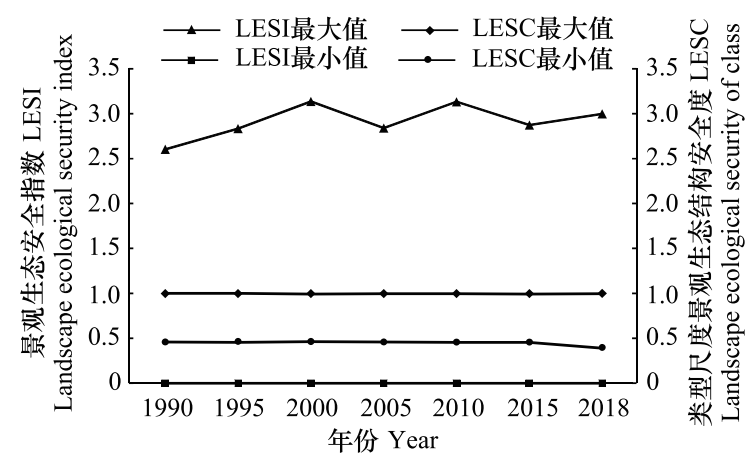

图 2 云南省 1990-2018 年各景观生态安全指数

Fig.2 Landscape Ecological Security Index of Yunnan Province, 1990-2018 $1.12 \%$ 、相对安全区减少 $0.13 \%$ 、较安全区减少 $0.48 \%$ 、 安全区减少 $9.74 \%$ 、极安全区增加 $14.21 \%$, 其中相对安全区(含) 至极危险区(含) 的面积共减少了 $3.98 \%$ 
(图 3)。结果表明,修正后的景观生态安全评价模型可以精确评价斑块的景观生态安全,能够反映区域内部 景观生态安全状况的细微变化。

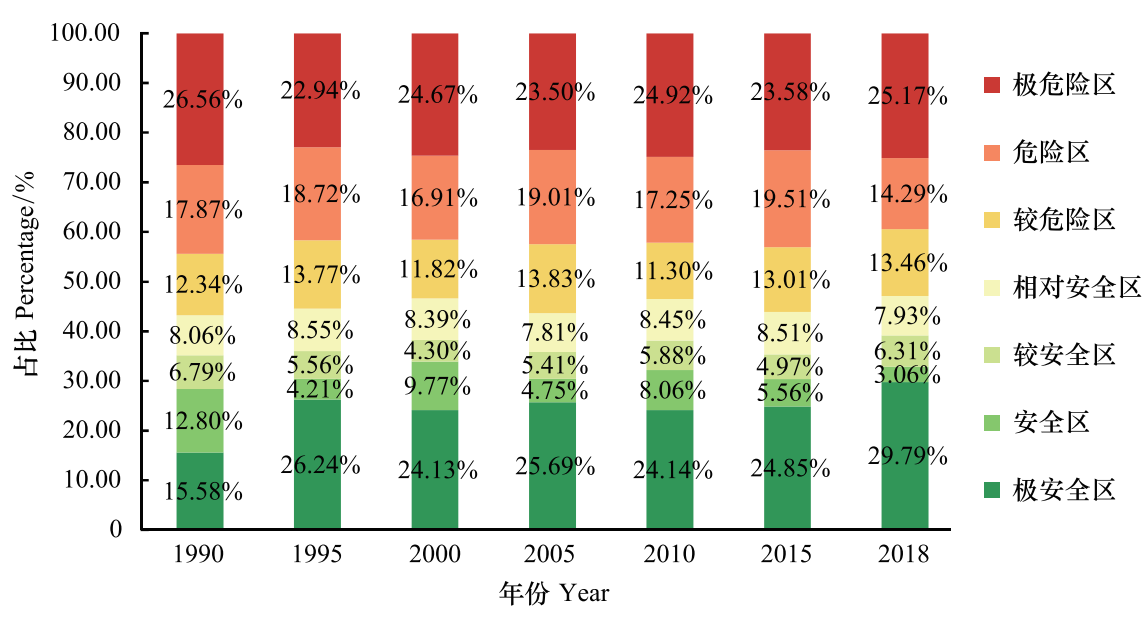

图 $32990-2018$ 年云南省景观生态安全各等级区面积占比

Fig.3 Proportion of landscape ecological security area in Yunnan Province, 1990-2018

\subsection{2 景观生态安全空间变化特征}

(1) 景观生态安全等级区空间变化特征

云南省景观生态安全极安全区、安全区和较安全区主要位于西北部、中部和东南部,并逐步向四周扩展。 极危险区和危险区间杂分布,在生态屏障内部形成孔洞,破坏了生态屏障的连续性和完整性(图 4)。自 2002 年生态修复工程全面启动至今, 云南省生态安全整体上得到显著改善,但在 2000 年和 2010 年景观生态安全 出现反复; 改革开放以来,云南省国内生产总值由 1980 年的第 22 位上升至 1999 年的第 18 位,粗放的经济发 展破坏了生态环境,使得 2000 年云南省的生态安全出现恶化;2010 年云南省发生百年一遇的特大旱灾 ${ }^{[43]}$, 耕 地减产、水域面积减少、森林火灾频发, 同时 1995 年以来云南烤烟业年均砍伐森林 $33333.33 \mathrm{hm}^{2[44]}$, 圈地毁林 等行为也对原始森林造成了严重破坏 ${ }^{[45]}$, 是造成南部边境热带森林生态屏障区景观生态安全等级波动的重 要原因。

景观生态安全等级提升最为明显的是青藏高原南缘滇西北高山峡谷生态屏障区、哀牢山-无量山山地生 态屏障区、金沙江干热河谷地带以及南部边境热带森林生态屏障区; 景观生态安全等级降低的地方主要分布 于滇中城市群区域, 其次是东南部喀斯特地带 (图 5), 二者皆为人类活动影响强烈的地区, 表明人类活动的干 扰对区域景观生态安全有较大影响。总之, 云南省景观生态安全特点表现为生态基础条件好的区域景观生态 安全等级提升明显而生态基础条件差的地区提升明显不足,且城市边缘是生态安全恶化的主要区域。因此, 在现有生态红线保护的基础上,还需加强对生态脆弱区的治理。

(2) 景观生态安全空间聚散特征

空间自相关分析结果表明, 1990-2018 年云南省 LESI 的 Global Moran's I 值的均值为-0.293,且变化趋 势平稳, 表明在 $99 \%$ 的置信度下 $(P=0.001)$, 云南省 LESI 有显著的空间负相关性(表 4)。1990-2018 年的 Global Moran's I 值总体变化不大 (图 6), 表明云南省景观生态安全的离散特征显著, 为空间负相关。

云南省斑块尺度景观生态安全由西北到东南呈现 “高-低集聚一低-高/高-高集聚一高-低集聚” 的空间格 局 (图 7)。其中“低-高” 型的斑块数量最多, 主要分布于滇中城市群区域, 其次是生态屏障的外围区域; “高低” 型面积最大, 主要布在青藏高原南缘滇西北高山峡谷生态屏障区和东南部喀斯特地带; “高-高”型主要分 布在哀牢山-无量山山地生态屏障区和南部边境热带森林生态屏障区; “低-低”型的斑块数量仅有一个,位于 滇中城市群区域。空间自相关分析结果表明,云南省景观斑块破碎, 以南部边境热带森林生态屏障区最为严 

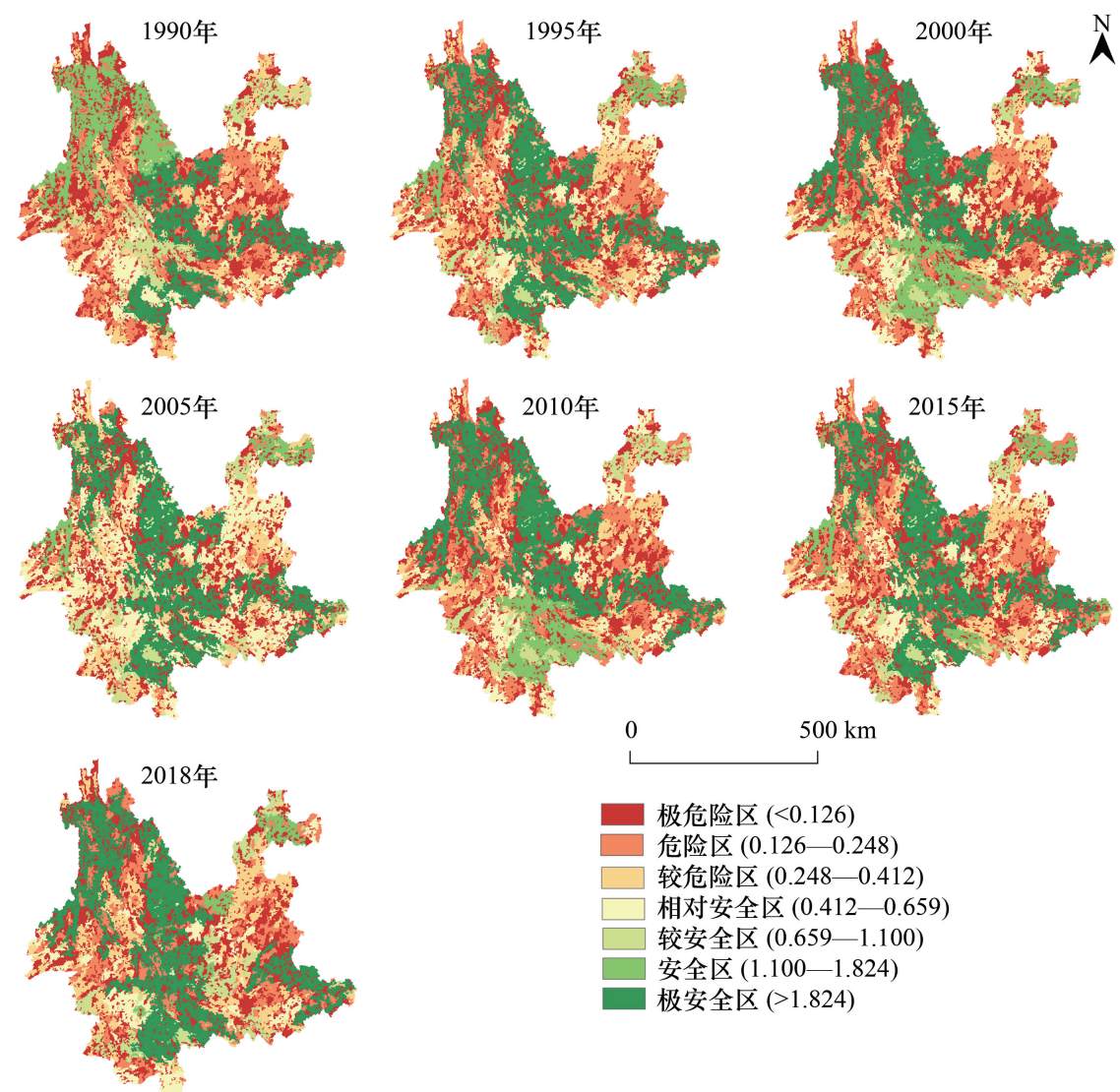

$500 \mathrm{~km}$

$$
\begin{aligned}
& \text { 极危险区 }(<0.126) \\
& \text { 危险区 }(0.126-0.248) \\
& \text { 较危险区 }(0.248-0.412) \\
& \text { 相对安全区 }(0.412-0.659) \\
& \text { 较安全区 }(0.659-1.100) \\
& \text { 安全区 }(1.100-1.824) \\
& \text { 极安全区 }(>1.824)
\end{aligned}
$$

图 4 1990-2018 年云南省景观生态安全等级区空间分布

Fig.4 Landscape ecological security in Yunnan Province, 1990—2018
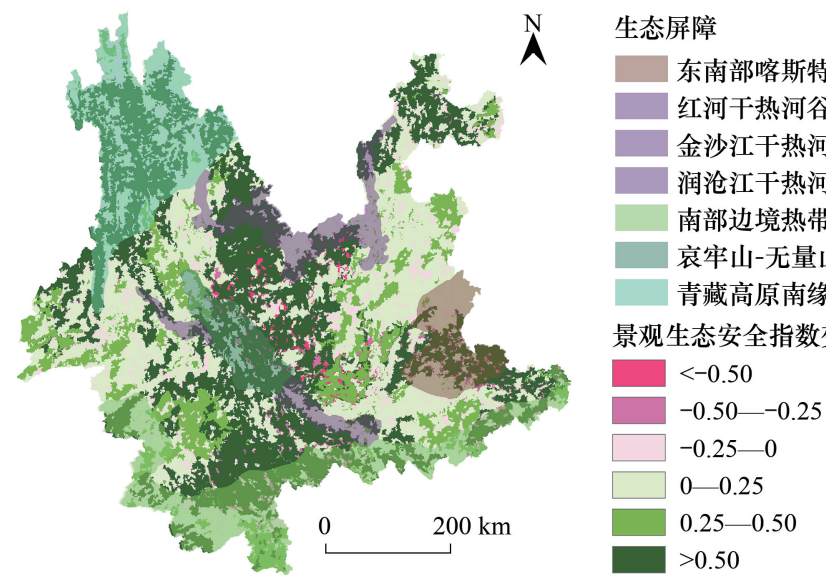

图 5 1990-2018 年云南省景观生态安全指数变化

Fig.5 Change of Landscape Ecological Security Index in Yunnan Province, 1990-2018

重; 滇中城市群区域的生态安全状况较差, 大量破碎斑块破坏了景观生态安全区域的整体性和连续性,呈现出 破碎化和脆弱性特征。 
表 $421990-2018$ 年云南省景观生态安全指数空间自相关结果

Table 4 The result of Global Moran's I of Landscape Ecological Security Index in Yunnan province, 1990—2018

\begin{tabular}{lccc||cccc}
\hline $\begin{array}{l}\text { 年份 } \\
\text { Year }\end{array}$ & $\begin{array}{c}\text { 莫兰指数 } \\
\text { Global Moran's I }\end{array}$ & $P$ & $Z$ & $\begin{array}{c}\text { 年份 } \\
\text { Year }\end{array}$ & $\begin{array}{c}\text { 莫兰指数 } \\
\text { Global Moran's I }\end{array}$ & $P$ & $Z$ \\
\hline 1990 & -0.34 & 0.001 & -25.538 & 2010 & -0.34 & 0.001 & -25.089 \\
1995 & -0.233 & 0.001 & -19.490 & 2015 & -0.227 & 0.001 & -18.8414 \\
2000 & -0.345 & 0.001 & -25.947 & 2018 & -0.338 & 0.001 & -24.9487 \\
2005 & -0.23 & 0.001 & -19.318 & 均值 Mean & -0.293 & & \\
\hline
\end{tabular}

2.2 云南省景观生态安全归因分析

因子探测结果显示,除坡向指标没有通过显著性检 验外,其余八个指标均在 $99 \%$ 显著性水平下对云南省 景观生态安全状况具有影响,其中人口密度 $(0.2386) 、$ 年平均温度 $(0.1601)$ 和海拔高度 $(0.1138)$ 对景观生态 安全状况影响最大 (表 5 ), 反映出景观生态安全较差的 区域人多地少和人类活动方式落后、频率高、影响大的 特征。

进一步分析各驱动因子的交互作用(表 6), 分析结 果表明因子间两两组合对云南景观生态安全的影响均 强于单一因子, 其中综合解释力较大的组合为: 6 对自 然和人文因子组合, $X_{1} \cap X_{6}(0.3574) 、 X_{1} \cap X_{7}(0.3243) 、$ $X_{4} \cap X_{6}(0.3988) 、 X_{4} \cap X_{7}(0.4076) 、 X_{5} \cap X_{6}(0.4041) 、$ $X_{5} \cap X_{7}(0.3580) ; 3$ 对纯自然因子组合, $X_{1} \cap X_{4}$ (0.3586)、 $X_{1} \cap X_{5}(0.3023) 、 X_{4} \cap X_{5}(0.3441) ; 1$ 对纯人 文因子组合, $X_{6} \cap X_{7}(0.3355)$ 。表明云南省景观生态安 全特征是自然环境和人类活动相互作用的结果。相较 于自然环境, 人类活动对生态安全的影响更为直接, 因 此在未来生态安全政策的制定过程中,应当严格限制城 市用地开发规模, 严守生态保护红线, 充分保障生态屏 障区的生态服务功能。

\section{3 结论与讨论}

\section{1 结论}

本研究选取斑块尺度的景观格局指数作为修正因 子, 对景观生态安全模型进行修正, 以评估 1990-2018 年云南省景观生态安全状况, 并使用地理探测器进一步 探讨影响云南省景观生态安全的因素。可得到如下 结论:

(1) 斑块尺度的景观生态安全模型对区域内部景 观生态安全的变化更加敏感, 能够反映区域内部多年景 观生态安全状况的细微变化; 相较于传统的类型尺度景观生态安全评价模型,其评价结果更加准确可靠。

(2) 在景观生态安全时间特征方面,云南省 1990-2018 年景观生态安全指数呈波动上升趋势, 景观生态 安全状况整体变好。在景观生态安全空间特征方面，“三屏两带”地区的景观生态安全等级提升最为明显,景

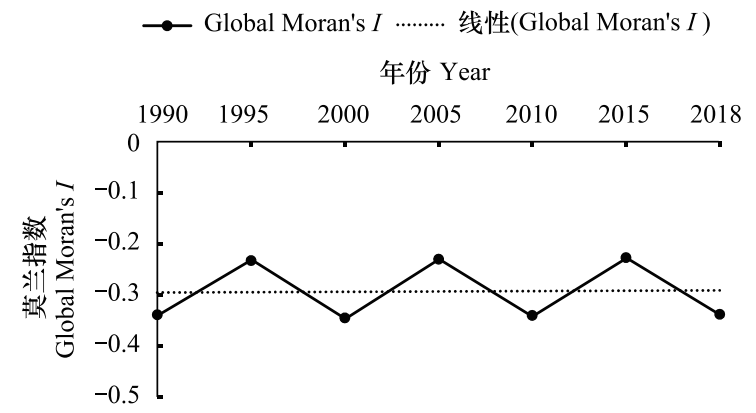

图 61990 -2018 年 Global Moran's I 指数

Fig.6 Results of Global Moran's I, 1990-2018

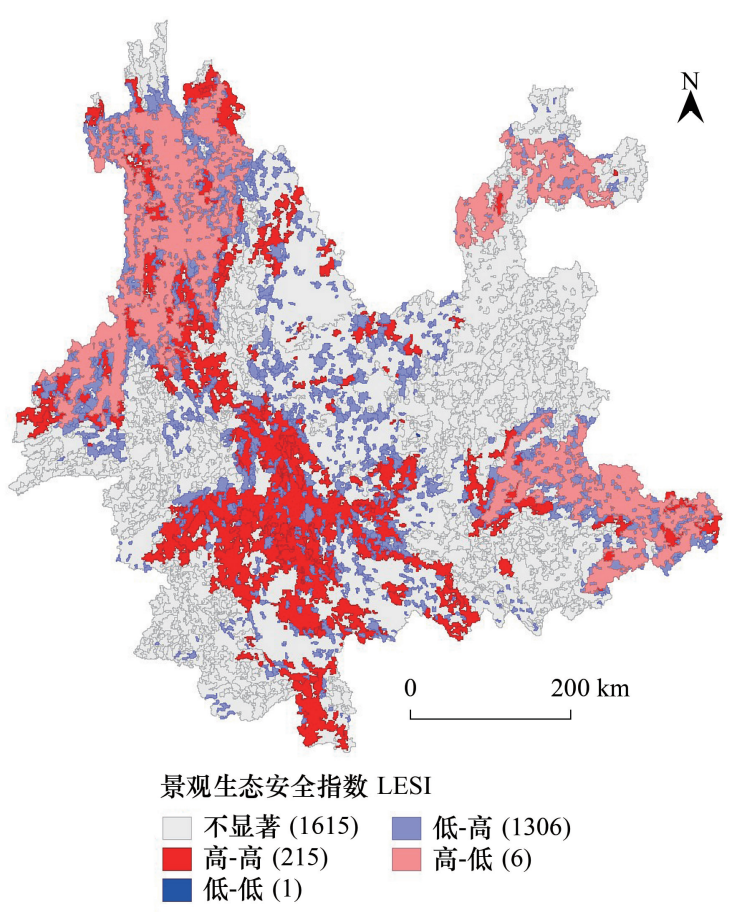

图 72018 年云南省景观生态安全指数 (LESI) 集聚图

Fig.7 Cluster of landscape ecological security index in Yunnan Province in 2018 
观生态安全恶化的地区则集中于人类活动影响强烈的滇中城市群和东南部喀斯特地带; 云南省景观生态安全 的空间分布呈“离散型”,内部斑块破碎、连续性差,反映出西南地区生态安全的脆弱性特征。

(3) 通过地理探测器分析得出, 目前影响云南省景观生态安全的主要驱动因子是人口密度、年平均温度 和海拔高度;多因子交互影响力大于单因子影响力,且自然因子对云南省景观生态安全的影响更显著。

表 5 云南省景观生态安全驱动因子指标

Table 5 Driving factors of landscape ecological security in Yunnan Province

\begin{tabular}{|c|c|c|c|c|}
\hline $\begin{array}{l}\text { 类别 } \\
\text { Class }\end{array}$ & $\begin{array}{l}\text { 名称 } \\
\text { Name }\end{array}$ & $\begin{array}{c}\text { 编号 } \\
\text { Numbering }\end{array}$ & $q$ & $P$ \\
\hline 地形因素 & 海拔高度 & $X_{1}$ & 0.1138 & 0.0000 \\
\hline \multirow[t]{2}{*}{ Topographical factor } & 坡向 & $X_{2}$ & 0.0066 & 0.6718 \\
\hline & 坡位 & $X_{3}$ & 0.0180 & 0.0000 \\
\hline 气候因素 & 年平均温度 & $X_{4}$ & 0.1601 & 0.0000 \\
\hline Climatic factor & 年平均降水 & $X_{5}$ & 0.0533 & 0.0000 \\
\hline 经济因素 & 人口密度 & $X_{6}$ & 0.2386 & 0.0000 \\
\hline Economic factor & 人均生产总值 & $X_{7}$ & 0.0626 & 0.0000 \\
\hline 区位因素 & 距水系距离 & $X_{8}$ & 0.0142 & 0.0000 \\
\hline Location factor & 距道路距离 & $X_{9}$ & 0.0717 & 0.0000 \\
\hline
\end{tabular}

表 6 云南省 2018 年景观生态安全驱动因子交互探测结果

Table 6 Interaction detector results of driving factors of landscape ecological security in Yunnan Province in 2018

\begin{tabular}{|c|c|c|c|c|c|c|c|c|c|}
\hline $\begin{array}{l}\text { 因子 } \\
\text { Factor }\end{array}$ & $\begin{array}{c}\text { 海拔高度 } \\
X_{1}\end{array}$ & $\begin{array}{c}\text { 坡向 } \\
X_{2}\end{array}$ & $\begin{array}{c}\text { 坡位 } \\
X_{3}\end{array}$ & $\begin{array}{c}\text { 年平均 } \\
\text { 温度 } \\
X_{4}\end{array}$ & $\begin{array}{c}\text { 年平均 } \\
\text { 降水 } \\
X_{5}\end{array}$ & $\begin{array}{c}\text { 人口密度 } \\
X_{6}\end{array}$ & $\begin{array}{c}\text { 人均生 } \\
\text { 产总值 } \\
X_{7}\end{array}$ & $\begin{array}{c}\text { 距水系 } \\
\text { 距离 } \\
X_{8}\end{array}$ & $\begin{array}{c}\text { 距道路 } \\
\text { 距离 } \\
X_{9}\end{array}$ \\
\hline 海拔高度 Altitude $X_{1}$ & 0.1138 & & & & & & & & \\
\hline 坡向 Aspect $X_{2}$ & 0.1198 & 0.0066 & & & & & & & \\
\hline 坡位 Slope position $X_{3}$ & 0.1287 & 0.0262 & 0.0180 & & & & & & \\
\hline $\begin{array}{l}\text { 年平均温度 } \\
\text { Mean annual temperature } X_{4}\end{array}$ & 0.3586 & 0.2494 & 0.1750 & 0.1601 & & & & & \\
\hline $\begin{array}{l}\text { 年平均降水 } \\
\text { Mean annual precipitation } X_{5}\end{array}$ & 0.3023 & 0.1358 & 0.0755 & 0.3441 & 0.0533 & & & & \\
\hline $\begin{array}{l}\text { 人口密度 } \\
\text { Population density } X_{6}\end{array}$ & 0.3574 & 0.2676 & 0.2455 & 0.3988 & 0.4041 & 0.2386 & & & \\
\hline $\begin{array}{l}\text { 人均生产总值 } \\
\text { Per capita gdp } X_{7}\end{array}$ & 0.3243 & 0.1556 & 0.0864 & 0.4076 & 0.3580 & 0.3355 & 0.0626 & & \\
\hline $\begin{array}{l}\text { 距水系距离 } \\
\text { Distance from water } X_{8}\end{array}$ & 0.1409 & 0.0302 & 0.0298 & 0.1868 & 0.0851 & 0.2502 & 0.0932 & 0.0142 & \\
\hline $\begin{array}{l}\text { 距道路距离 } \\
\text { Distance from road } X_{9}\end{array}$ & 0.1836 & 0.0855 & 0.0808 & 0.2406 & 0.1681 & 0.2618 & 0.1501 & 0.0853 & 0.0717 \\
\hline
\end{tabular}

\section{2 讨论}

(1) 在景观生态安全评价模型方面, 当前学者评价景观生态安全的尺度主要是类型尺度 ${ }^{[46-49]}$ 和景观尺 度 ${ }^{[00-51]}$, 很少从斑块尺度进行研究。陈昆仑等 ${ }^{[52]}$ 在评价湖泊景观生态安全时引人了斑块面积占比因子, 是对 传统生态安全评价模型的有效改进; 在此基础上,本研究构建的斑块尺度景观生态安全评价模型对云南省景 观生态安全状况的变化敏感, 能够反映景观生态安全状况的过渡特征与空间分布特征, 可以提高生态安全的 评价精度。同时斑块尺度景观生态安全评价模型仍有一定的不足, 在斑块修正指数的选取和权重确定方面还 需进一步讨论。

(2) 在景观生态安全归因方面, 前人对于景观生态安全影响因素的分析以单因子为主 ${ }^{[29,53]}$, 而景观生态 安全归因分析的复杂性在于各驱动因子并非独立作用于因变量。本研究使用地理探测器对影响云南省景观 
生态安全的主要驱动因子的交互作用进行分析, 发现多因子交互作用比单因子的影响力更为显著, 为景观生 态安全的多因子交互分析提供了一定的参考。受限于资料获取难度,本研究的归因分析尚有不足之处。如区 域用水量以及政策性等因素未纳人指标体系,且未对驱动因子影响力随时间变化的特征进行研究以分析各年 的主要驱动因子,在后续研究中需要改进。

\section{参考文献 (References) :}

[ 1 ] 吴庭天, 陈宗铸, 雷金睿, 陈小花, 李苑菱. 琼北火山熔岩湿地生态安全格局研究. 生态学报, 2020, 40(23): 8816-8825.

[2] 谷树忠, 胡咏君, 周洪. 生态文明建设的科学内涵与基本路径. 资源科学, 2013, 35(1): 2-13.

[ 3 ] 邭庆治. 区域生态文明建设推进的云南实践——环境政治视角. 鄱阳湖学刊, 2019, 58(1) : 19-31.

[ 4] 张纪华. 学习贯彻党的十九大精神 为建设美丽云南砥硛前行. 西南林业大学学报: 社会科学, 2018, 2(1): 1- 10 .

[ 5 ] 李益敏, 谢亚亚, 刘雪斌, 段亚苹, 朱军. 基于 GIS 的云南泸水市生态安全评价. 人民长江, 2019, 50(6): 56-62, 187-187.

[ 6 ] 包艳丽, 张洪. 基于 CRITIC 权灰靶模型的云南省土地生态安全评价. 上海国土资源, 2020, 41(2)：48-53.

[ 7 ] 杨育华, 杨洪福, 段燕楠, 张文丽, 闻睿. 云南省水生态现状及其保护对策. 环境科学导刊, 2019, 38(S1): 22-26.

[8] 张凯黎. 云南省生态文明社会构建的实践创新研究. 中国集体经济, 2019，606(22)：159-160.

[ 9 ] 张洪,李中元, 李彦. 基于生态安全的山地城镇土地可持续利用模式研究一一云南大理市为例. 地理研究, 2019, 38(11): 2681- 2694.

[10] 王娟, 崔保山, 刘杰, 姚华荣, 翟红娟. 云南澜沧江流域土地利用及其变化对景观生态风险的影响. 环境科学学报, 2008, 28 (2) : 269-277.

[11] Peng J, Pan Y J, Liu Y X, Zhao H J, Wang Y L. Linking ecological degradation risk to identify ecological security patterns in a rapidly urbanizing landscape. Habitat International, 2018, 71: 110-124.

[12] Aguilera F, Valenzuela L M, Botequilha-Leitão A. Landscape metrics in the analysis of urban land use patterns: a case study in a Spanish metropolitan area. Landscape and Urban Planning, 2011, 99(3/4) : 226-238.

[13] Ma L B, Bo J, Li X Y, Fang F, Cheng W J. Identifying key landscape pattern indices influencing the ecological security of inland river basin: the middle and lower reaches of Shule River Basin as an example. Science of the Total Environment, 2019, 674: 424-438.

[14] Zhang R S, Pu L J, Li J G, Zhang J, Xu Y. Landscape ecological security response to land use change in the tidal flat reclamation zone, China. Environmental Monitoring and Assessment, 2016, 188(1): 1.

[15] Tress B, Tress G, Décamps H, D'hauteserre A M. Bridging human and natural sciences in landscape research. Landscape and Urban Planning, 2001, 57(3/4): 137-141.

[16] Haber W. Landscape ecology as a bridge from ecosystems to human ecology. Ecological Research, 2004, 19(1) : 99-106.

[17] Yin H W, Kong F H, Hu Y M, James P. Assessing growth scenarios for their landscape ecological security impact using the SLEUTH urban growth model. Journal of Urban Planning and Development, 2016, 142(2) : 05015006.

[18］俞孔坚, 李迪华, 段铁武. 生物多样性保护的景观规划途径. 生物多样性, 1998，6(3)：205-212.

[19] 俞孔坚. 生物保护的景观生态安全格局. 生态学报, 1999, 19(1) : 8-15.

[20] 肖笃宁, 陈文波, 郭福良. 论生态安全的基本概念和研究内容. 应用生态学报, 2002, 13(3) : 354-358.

[21] 程国栋, 肖笃宁, 王根绪. 论干旱区景观生态特征与景观生态建设. 地球科学进展, 1999, 14(1)：11-15.

[22] 黎晓亚, 马克明, 傅伯杰, 牛树奎. 区域生态安全格局一一设计原则与方法. 生态学报, 2004, 24(5): 1055- 1062.

[23] 马克明, 傅伯杰, 黎晓亚, 关文彬. 区域生态安全格局一一概念与理论基础. 生态学报, 2004, 24(4)：761-768.

[24] 陈利顶, 傅伯杰, 赵文武. “源”“汇”景观理论及其生态学意义. 生态学报, 2006, 26(5)：1444-1449.

[25] 陈利顶, 傅伯杰, 徐建英, 巩杰. 基于“源-汇” 生态过程的景观格局识别方法一一景观空间负荷对比指数. 生态学报, 2003, 23(11)： 2406-2413.

[26] 陈鹏, 潘晓玲. 干旱区内陆流域区域景观生态风险分析一以阜康三工河流域为例. 生态学杂志, 2003, 22(4): 116-120.

[27] 裴欢, 魏勇, 王晓妍, 覃志豪, 侯春良. 耕地景观生态安全评价方法及其应用. 农业工程学报, 2014, 30(9) : 212-219.

[28] 李晓燕, 张树文. 基于景观结构的吉林西部生态安全动态分析. 干旱区研究, 2005(1)：57-62.

[29］彭文君, 舒英格. 喀斯特山区县域耕地景观生态安全及演变过程. 生态学报, 2018, 38(3)：852-865.

[30] Daily G C. Nature's Services: Societal Dependence on Natural Ecosystems. Washington: Island Press, 1997.

[31] 赵䈗青, 王兴友, 谢鹏飞, 张龙飞. 基于结构与功能安全性的景观生态安全时空变化一一人工园林大面积种植区西盟县为例. 地理研 究, 2015, 34(8): 1581-1591.

[32] 顾泽贤, 赵篠青, 高翔宇, 谢鹏飞. 澜沧县景观格局变化及其生态系统服务价值评价. 生态科学, 2016, 35(5): 143-153.

[33] 谢高地, 张彩霞, 张雷明, 陈文辉, 李士美. 基于单位面积价值当量因子的生态系统服务价值化方法改进. 自然资源学报, 2015, 30(8)： 
1243-1254.

[34] 潘洪义, 张琴, 李加安, 徐捷, 黄佩. 基于动态当量的彝汉交错深度贫困区生态系统服务价值时空演变研究. 生态学报, 2020, 40(22) : 8218-8229.

[35] 张昕, 郭小平, 李鹏飞, 冯崉栋, 郭光. 基于景观功能评价法 (LFA) 的 5 种恢复模式景观功能综合评价: 以乌海市典型露天煤矿排土场为 例. 生态与农村环境学报, 2020,36(7): 897-904.

[36] 林金煌, 吴思佳, 陈文惠, 王智荵, 程瑞肜, 陈增文, 余锦慧. 闽三角地区农田景观格局演变及其生态服务功能研究. 生态科学, 2019, 38(1): 194-202.

[37] Jiang X, Xu S G, Liu Y Y, Wang X D. River Ecosystem Assessment and Application in Ecologicalrestorations a Mathematical Approach Based on Evaluating Itsstructure and Function. Ecological Engineering, 2015, 76: 151-157.

[38] 周兴东, 于胜文, 赵长胜, 曹后龙. 空间粒度变化对景观格局指数的影响一以徐州地区为例. 测绘科学, 2009, 34(1): 173-173, 201-202.

[39］申卫军, 邬建国, 林永标, 任海, 李勤奋. 空间粒度变化对景观格局分析的影响. 生态学报, 2003, 23(12): 2506- 2519.

[40］徐丽, 市晓庆, 秦小林, 张庆国, 刘琳. 空间粒度变化对合肥市景观格局指数的影响. 应用生态学报, 2010, 21(5): 1167-1173.

[41] 高艳, 毕如田, 曹毅. 空间粒度变化及土地利用分类对景观指数的影响一一山西省闻喜县为例. 中国生态农业学报, 2010, 18(18): 1076-1080.

[42] 王劲峰, 徐成东. 地理探测器: 原理与展望. 地理学报, 2017, 72(1): 116-134.

[43] 黄新会, 李小英, 穆兴民, 王克勤, 田昆, 段昌群, 于福科. 2010 年中国西南特大干旱灾害: 从生态学视角的审视. 水土保持研究, 2013, $20(4)$ : 282-287, 292-292.

[44] 周琼. 环境史视野下中国西南大旱成因刍论一一基于云南本土研究者视角的思考. 郑州大学学报 (哲学社会科学版), 2014, 47(5)： 132-141.

［45］李佩哲. 当代中国的生态建设和改革一一印尼金光集团在云南山区毁林造纸为例. 思想战线, 2011, 37(S2)：269-271.

[46] 吕天阳, 郭岱. 基于遥感和 PSR 模型的城市景观生态安全评价. 绿色科技, 2019, 4(6)：144-148.

[47] 袁媛, 罗志军, 赵杰, 齐松. 基于景观结构和空间统计学的南昌市景观生态安全评价. 水土保持研究, 2020, 27(3): 247-255.

[48］刘顺金金, 黄云. “三生空间”视角下万州区景观生态安全评价及其耦合特征分析. 水土保持研究, 2020, 27(6) : 308-316.

[49] 李雪冬, 杨广斌, 周越, 李冰, 张旭亚. 基于 $3 S$ 技术的岩溶地区城市景观生态安全评价——以贵阳市为例. 中国岩溶, 2016, 35(3): 340-348.

[50］王一山, 张飞, 陈瑞, 齐亚霄, 刘长江. 乌鲁木齐市土地生态安全综合评价. 干旱区地理, 2021, 44(2) : 427-440.

[51] 蔡汉, 朱权, 罗云建, 马坤. 快速城镇化地区耕地景观生态安全格局演变特征及其驱动机制. 南京林业大学学报 (自然科学版), 2020, $44(5): 181-188$.

[52］陈昆仑, 齐漫, 王旭, 黄耿志. 1995-2015 年武汉城市湖泊景观生态安全格局演化. 生态学报, 2019, 39(5): 1725-1734.

[53] 韩逸, 郭熙, 江叶枫, 饶否, 孙凯, 李婕, 王澜珂. 南方丘陵区耕地景观生态安全影响因素及其空间差异. 生态学报, 2019, 39(17)： 6522-6533. 